\title{
From the editors
}

Craig A. Snyder, in a book titled Contemporary Security and Strategy, noted that the broad idea of security provides strategic studies with institutional status and political legitimacy. Yet, the military core endows strategic studies, as a scholarly discipline, with intellectual coherence. ${ }^{1}$ This edition of Scientia Militaria, the South African Journal of Military Studies, reflects this reality with a very broad range of articles - from sexual behaviour and poetry to military intervention. Yet, the underlying commonality is an emphasis on military issues.

Carol Allais, in her article on the sexual behaviour of peacekeepers, points out that the sexual perpetrators include members of the statutory armed and security forces, paramilitary groups, non-state armed groups and civilians, including refugees and displaced persons. She argues that this phenomenon can only be dealt with through an understanding of the social identities of the peacekeepers and the social conditions under which these identities are constructed. Allais therefore suggests that the training of peacekeepers should be more than the transfer of knowledge and skills. She particularly highlights the constructive role of peer education in changing the sexual behaviour and attitudes of peacekeepers in preparation for peace missions. Such peer education programmes are successful in changing behaviour because they provide a context in which individuals are given space to refashion their social and sexual identities in a collective way.

Colonel Eugene J. Palka from the United States Military Academy, West Point, contributed a very interesting article on the so-called 'green line' as one of the most significant impediments to long-term stability in Iraq. The green line, which separates Iraq's Kurdish and Arab populations, has a long history and has in recent times been defined as the area controlled by the Kurdish Regional Government, which was recognised by the Iraqi Transitional Government when it passed the Transitional Administrative Law (TAL) in 2004. However, defining this Kurdish autonomous region with precise boundaries remains an elusive task. The status of Kirkuk, in particular, is contentious. The author contends that difficulties such as insurgent group activity, sectarian violence, corruption, sponsored terrorism and an underdeveloped economic infrastructure will probably impede progress toward

\footnotetext{
${ }^{1}$ Snyder, CA (ed), Contemporary Security and Strategy. New York: Routledge, 1999 , p. 3
} 
peace and stability in Iraq. However, none of these challenges compares to the worst-case scenario of possible conflict between Iraq's Kurds and Arabs.

A very interesting contribution on military intervention in Africa after the Cold War was received from Godfrey Ramuhala. The article, based on research done as part of his studies in the Faculty of Military Sciences, explains the extent to which military intervention in Africa has evolved since the end of the Cold War, in terms of theory and practice, and places the emphasis on a number of case studies of military interventions in Africa. Ramuhala argues that the unsuccessful cases of military intervention attracted much scholarly attention and controversy, given their prolonged nature and difficulty in terms of conclusion. At the same time, though, the successful cases were relatively short and attracted little scholarly attention and controversy. He concludes that matters of who should intervene militarily in Africa remains marred in controversy, especially when those inclined to do so reside in the West and when the UN appears divided on the issue. Africa, though, remains posed to encounter military interventions in future.

Optimising the effectiveness and efficiency of public institutions and private companies through management and leadership is rooted in a continuous search for better approaches or ways of doing. In their contribution, Gerhard de Coning and Gerrit van der Waldt, introduce an Integrated Service Excellence Model (ISEM) for empowering the leadership core of the capital-intensive military test and evaluation facilities to provide strategic military test and evaluation services and to improve service excellence continuously by ensuring that all activities necessary to design, develop and implement a test and evaluation service are effective and efficient. The article concludes with the observation that, although the ISEM was developed in and for the military test and evaluation facilities, the application of the model by the leadership core is also viable for other service delivery departments, both in the public and private sector, in order to add citizen value.

The Border War in Namibia is an ingrained part of the collective memory of a particular generation of white South Africans in very much the same way that the wars in Vietnam and Afghanistan feature in the societal memory of a generation of Americans and Russians. Thus, it is no small wonder that the Border War is a continued theme in the Journal of South African Military Studies. The article by Andre van der Bijl on poetry as an element of the apartheid military discourse is a good example of the ingrained nature of that war, and the military who fought that war, on the collective memory of many South Africans. Van der Bijl uses a 1981 compilation of pencil sketches and short poetic works by Peter Badcock, published as Images of war, to argue that a state apparatus can gain popular support for sociologically unacceptable practices. The simple blank verse and images of racial diversity, romance and implied tradition in the publication provide some 
understanding of the underlying power relations and ideological processes of the time.

Lieneke Eloff de Visser provides a very interesting overview in her article on the wide variety of tensions that underpinned the hearts and minds programme of the South African military in the Border War. The article, based on a study at the University of Utrecht, points out that the South African counterinsurgency doctrine acknowledged the importance of securing the allegiance and cooperation of the population. At the same time, though, factors such as internal institutional differences, political considerations, public administrative ineffectiveness and police actions in the operational area undermined the military's capacity to implement a strategically successful hearts and minds programme.

This edition concludes with a very interesting opinion piece in the form of a review essay by Prof. Leopold Scholtz on the standard of research on what has became known in South Africa as the Battle of Cuito Cuanavale. Scholtz draws a very clear line between what he calls the 'non-researchers' and the 'serious researchers'. The first category, in his view, are those who do no or virtually no real research into the events at Cuito Cuanavale, but "uncritically copy what politicians and politically correct academics have to say about the subject". The conclusions of this school of research is a one-sided and distorted picture of what went on at Cuito Cuanavale and the Border War in general due to this school's admiration for Cuba and its president, Fidel Castro, and their revulsion at apartheid South Africa. The work of the second school of research, Scholtz argues, "is based on good research" and, although it displays certain gaps, is factually much more reliable.

The editors

Abel Esterhuyse \& Ian Liebenberg 